\title{
Study of Coronary Sinus and its Tributaries in Pigs
}

\author{
Diana Marcela Reyes-Blanco ${ }_{1}$, Jairo José Rivera-Piñeres, ${ }_{1}$ Fabián Alejandro \\ Gómez-Torres, MSc. ${ }_{2}$, Luz Stella Cortes-Machado, Esp. ${ }_{2}$ \\ ${ }_{1}$ Student of the Faculty of Veterinary Medicine, University Cooperative of Colombia, Bucaramanga, Colombia \\ ${ }_{2}$ Research Group in Animal Sciences, Faculty of Veterinary Medicine and Animal Science, \\ University Cooperative of Colombia, Bucaramanga, Colombia
}

Recibido: 9 de mayo del 2015 Aprobado: 9 de noviembre del 2015

Autor de correspondencia: Fabián Alejandro Gómez, School of Veterinary Medicine, Universidad Cooperativa de Colombia, Bucaramanga, Colombia. (+57) 6854500 ext 7072 CP 680002 e-mail: fabian.gomez@campusucc.edu.co

Cómo citar este artículo: Reyes-Blanco DM, Rivera-Piñeres JJ, Gómez-Torres FA, Cortes-Machado LS. Study of coronary sinus and its tributaries in pigs. Spei Domus. 2015;11(23) 25-31. doi: http://dx.doi.org/10.16925/sp.v11i23.1365

\begin{abstract}
Introduction: Similarities between the bodies of pigs and humans have encouraged studies in comparative anatomy, trying to describe in detail the anatomical variations that could influence in the xenotransplantation; given that advances in genetics, immunology and biotechnology are large, this possibility is not far. The objective of this work was to make contributions to the vascular study of porcine heart. Methodology: 60 porcine hearts, with an average of five months old and weighing $85-95 \mathrm{~kg}$, were obtained from plant Vijagual. After receipt hearts were kept in water for six hours, then they were perfused with polyester resin semi-synthetic and mineral blue color, moreover the left coronary artery was perfused with red mineral color. Subsequently, the hearts were subjected to a process of partial corrosion with potassium hydroxide (15\%), then the coronary sinus and its tributary branches were dissected from its origin to its distal segments, path, shapes, sizes, anastomosis and presence of registered anatomical variations. Photographic record of the samples was performed. Results: The origin of the distal caliber of Great cardiac vein $(5.36+/-1,04 \mathrm{~mm})$ was determined from the apex at $70 \%$ of anatomical pieces studied, and the ventricular groove paraconal in $30 \%$ of the pieces analyzed. The arteriovenous trigone was found in 58 of the cardiac structures studied (96.66\%). Conclusion: The description of the anatomic variations present in the pig heart structure will contribute to the possibility of xenotransplantation and also provides data for the development of studies on cardiovascular surgery and certain diseases of clinical and epidemiological importance.
\end{abstract}

Keywords: cardiac circulation, comparative anatomy, coronary sinus, heart, venous circulation. 


\section{Estudio del seno coronario y sus tributarias en cerdos}

Resumen. Introducción: las similitudes entre el cuerpo del cerdo y el del ser humano han fomentado estudios de anatomía comparada que intentan describir en detalle las variaciones anatómicas que podrían tener influencia en los xenotrasplantes. Teniendo en cuenta que los avances en genética, inmunología y biotecnología son grandes, esta no es una posibilidad lejana. El objetivo de este trabajo era contribuir al estudio vascular del corazón porcino. Metodología: 60 corazones porcinos, con un promedio de cinco meses de edad y un peso de 85-95 $\mathrm{kg}$, se obtuvieron de la planta Vijagual. Después de mantener los corazones recibidos en agua durante seis horas, se sometieron a perfusión con resina de poliéster semisintética y color azul mineral. Además, la arteria coronaria izquierda se perfundió con color rojo mineral. Posteriormente, los corazones se sometieron a un proceso de corrosión parcial con hidróxido de potasio (15\%) y, luego, el seno coronario y sus ramas tributarias fueron disecados desde su origen hasta sus segmentos distales, registrando trayectorias, formas, tamaños, anastomosis y presencia de variaciones anatómicas. Se realizó un registro fotográfico de las muestras. Resultados: se determinó que el origen del calibre distal de la vena cardíaca magna (5,36 +/- 1,04 $\mathrm{mm}$ ) era el ápice en el $70 \%$ de las piezas anatómicas estudiadas y el surco intraventricular paraconal en el 30\% de las piezas analizadas. El trígono arteriovenoso se encontró en 58 de las estructuras cardíacas estudiadas (96,66\%). Conclusión: la descripción de las variaciones anatómicas presentes en la estructura cardíaca del cerdo contribuirá a la posibilidad de los xenotrasplantes y también suministra datos para el desarrollo de estudios sobre cirugía cardiovascular y ciertas enfermedades de importancia clínica y epidemiológica.

Palabras clave: circulación cardíaca, anatomía comparada, seno coronario, corazón, circulación venosa.

\section{Estudo do seio coronário e suas tributárias em suínos}

Resumo. Introdução: as semelhanças entre o corpo do porco e o do ser humano têm fomentado estudos de anatomia comparada que tentam descrever em detalhe as variações anatômicas que poderiam ter influência nos xenotransplantes. Considerando que os avanços em genético, imunologia e biotecnologia são grandes, esta não é uma possibilidade distante. O objetivo deste trabalho foi contribuir ao estudo vascular do coração suíno. Metodologia: 60 corações porcinos, com uma média de cinco meses de idade e um peso de 85-95 quilos, obtiveram-se da planta Vijagual. Após manter os corações recebidos em água durante seis horas, foram submetidos a perfusão com resina de poliéster semissintética e de cor azul mineral. Além disso, a artéria coronariana esquerda se irrigou com cor vermelha mineral. Em seguida, os corações foram submetidos a um processo de corrosão parcial com hidróxido de potássio (15\%) e, depois, o seio coronariano e suas ramificações tributárias foram dissecados desde sua origem até seus segmentos distais, registrando trajetórias, formas, tamanhos, anastomose e presença de variações anatômicas. Realizou-se um registro fotográfico das amostras. Resultados: determinou-se que a origem do calibre distal da veia cardíaca magna $(5,36+/-1,04 \mathrm{~mm})$ foi o ápice em $70 \%$ das peças anatômicas estudadas, e o sulco interventricular paraconal em $30 \%$ das peças analisadas. O trígono arteriovenoso se encontrou em 58 das estruturas cardíacas estudadas (96,66 \%). Conclusão: a descrição das variações anatômicas presentes na estrutura cardíaca do porco contribuirá para a possibilidade dos xenotransplantes e também fornece dados para o desenvolvimento de estudos de cirurgia cardiovascular e certas doenças de importância clínica e epidemiológica.

Palavras-chave: circulação cardíaca, anatomia comparada, seio coronariano, coração, circulação venosa. 


\section{Introduction}

Comparative anatomy studies, especially of pig organs, have established that there is some similarity with human bodies, however, the knowledge and characterization of hearts', venous system of pigs $[1,2]$ is still essential. Comparative anatomy studies are still limited and do not provide complete descriptions of the distribution patterns of all the veins, so a deeper characterization of these structures is necessary $[3,4]$.

Different reports have been developed to describe the morphology of the coronary venous system and its tributaries in pigs and humans [5-7], likewise various techniques have been applied for description $[8,9]$, contributing to the knowledge of the circulatory system of both species.

Studies described the pig coronary venous system that consists mostly of the coronary sinus (Cs), which is located within the left atrioventricular furrow [10]. The great cardiac vein (GCV) ascends the paraconal interventricular sulcus (PIS) and returns within the same row to join down the left azygos vein, being here where it becomes the coronary sinus [1]. In pigs azygos vein (Av) and the Cs are the dominant vessels. As the cs passes around the mural mitral valve flap, it receives marginal veins and then the crux cordis level the middle cardiac vein (MCV) and minus cardiac [1].

In humans the arteriovenous trigone (AVT) of the heart is formed by the intersection of three cardiac vessels, GCV and circumflex artery and anterior interventricular, which are located in the upper portion of the left ventricle between the arterial cone and the atrium left, on the pulmonary face or left hearth [11]. In humans there are clear morphological descriptions of the cardiovascular system, however, for these pigs and other mammals these are still unknown.

This study aims to describe the morphometry of the porcine coronary venous system, performing a differential analysis with human, allowing this species as a model of interventional cardiovascular procedures.

\section{Materials and methods}

For the development of this cross-sectional study 60 pig hearts (55 males and five females) of different commercial breeds were evaluated (cross-breeds Pietrain, Belgian Landrace and Large White). The anatomical pieces were obtained in plant Vijagual sacrifice of Bucaramanga, and belonged to animals for consumptione, with an average age of five months and an average weight of $85-95 \mathrm{~kg}$.

Porcine hearts were received frozen, were immersed in tap water for a period of six hours, seeking full exsanguination.Subsequentlyplicationarcuatewith 2.0 silk around the opening Cs is performed, and No. 14 catheter its settled, whereby semi-synthetic polyester resin is perfused (Palatal GP40L $85 \%$ and $15 \%$ styrene) and mineral blue color. Furthermore, the left coronary artery is perfused with red mineral color for the description of the characteristics of AVT according to Pejkovic and Bogdanovic [12]; and open at its lower end and closed top; open top and bottom; lower and upper closed; closed bottom and open top.

After this process the hearts were subjected to a process of partial corrosion with potassium hydroxide (кон) to $15 \%$, looking to remove the subepicardial fat, then the coronary sinus and its tributary branches were dissected from its origin to its distal segments, registering their paths, shapes, sizes, anastomosis and presence of anatomical variations. The external diameter of these vessels was measured $0.5 \mathrm{~cm}$ from their respective sources by using a digital caliper (Mitutoyo ${ }^{\circ}$ ).

Photographic record of each of the samples analyzed to support the results and the data were entered into a database for further analysis.

The $\mathrm{t}$ test for continuous variables and ChiX2 test for discrete variables was applied. For data analysis - statistical program "3.5.4 Epi Info" was used. The significance level was set at $\mathrm{p}<0.05$.

\section{Results}

For the development of this cross-sectional study 60 pig hearts were evaluated, with an average weight of 377.6 grams ( \pm 96.1 grams). To begin describing the morphology of porcine coronary venous system, the origin of the great cardiac vein (GCV) was determined and found that in 42 of the pieces studied (70\%) it originated at the apex, and in the remaining $18(30 \%)$ this structure originated in the lower third of paraconal interventricular sulcus (PIS). Likewise the distal caliber determined GCV, 
in which a caliber of $5.36 \pm 1.04 \mathrm{~mm}$ was observed (figure 1).

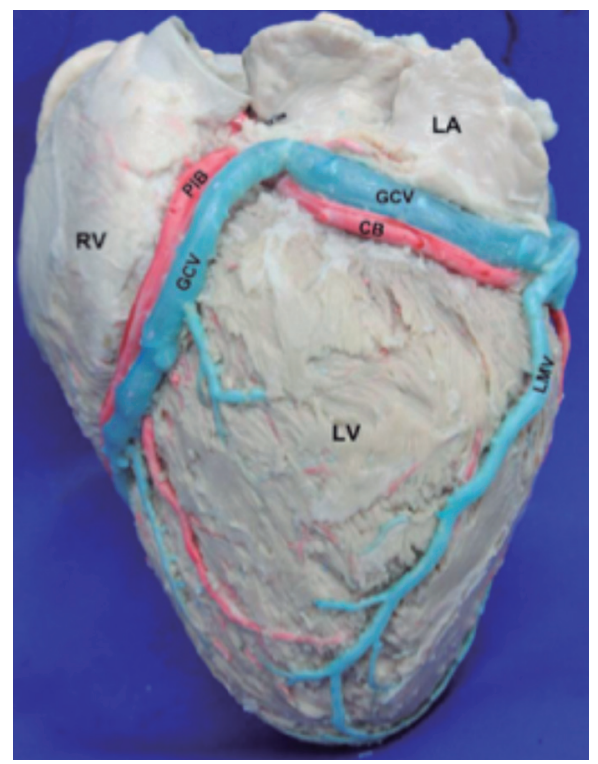

Figure 1. Left surface of the heart. LA: Left atrium. LV: Left ventricle. RV: Right ventricle. GCV: Great cardiac vein. LMV: Left marginal vein. PIB: Paraconal interventricular branch. Св: Circumflex branch Source: Compiled by the authors

The formation and path of the arteriovenous trigone (AVT) was shown, a comparison to the first characteristic determined by the presence or absence was studied and found that in 58 hearts $(96.66 \%)$ this structure is present, while in the other two $(3.33 \%)$ there is no such structure.

Arteriovenous trigone configuration was described as open: top and bottom found in thirteen hearts (21.6\%; figure 2), closed: top and bottom, configuration present in eleven of the pieces studied (18.3\%; figure 3); opened lower and closed above reported for 30 hearts (50\%; figure 4), and finally opened higher and closed lower was presented in four cases (6.66\%; figure 5). For two (3.33\%) anatomical pieces included in the study, it was not possible to describe the configuration.

The origin of the left marginal vein was also determined, it was found that it begins from the apex and it was present in 22 hearts (36.6\%), the origin in the lower third was found in ten cases

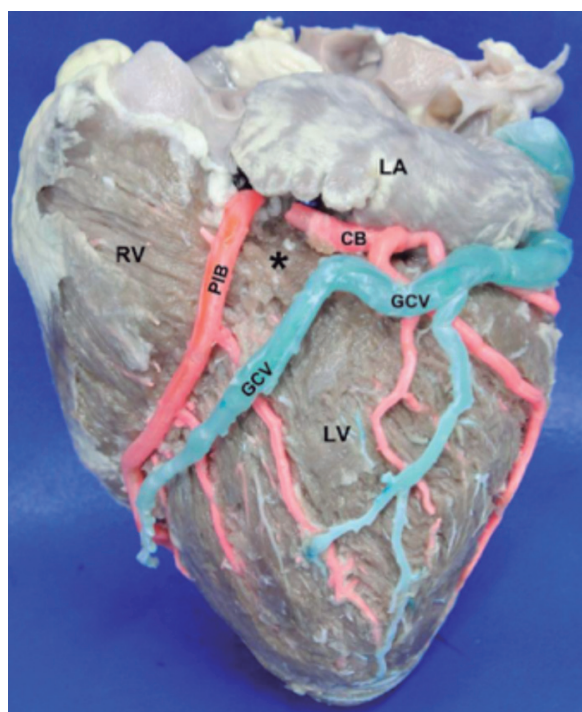

Figure 2. Left surface of the heart. LA: Left atrium. LV: Left ventricle. RV: Right ventricle. GCV: Great cardiac vein. PIB: Paraconal interventricular branch.

Св: Circumflex branch. $\left({ }^{*}\right)$ : Arteriovenous triangle, open at the lower end and top

Source: Compiled by the authors

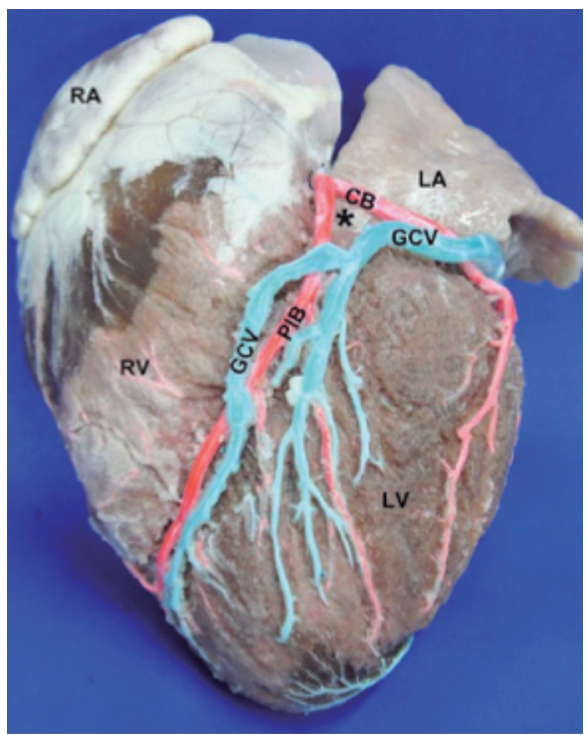

Figure 3. Left surface of the heart. LA: Left atrium. RA: Right atrium. LV: Left ventricle. RV: Right ventricle. GCV: Great cardiac vein. PIB: Paraconal interventricular branch. Св: Circumflex branch. $\left(^{*}\right)$ : Arteriovenous triangle, closed at the lower end and top Source: Compiled by the authors 


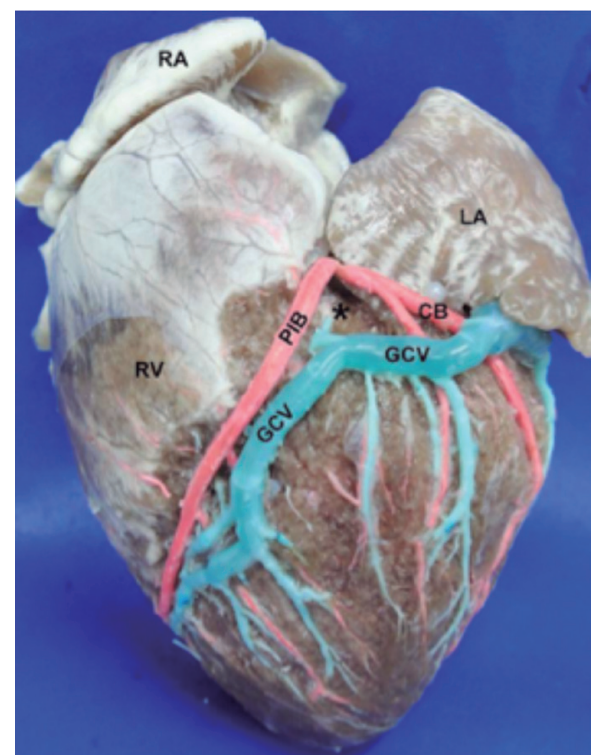

Figure 4. Left surface of the heart. LA: Left atrium. RA: Right atrium. LV: Left ventricle. RV: Right ventricle. GCV: Great cardiac vein. PIB: Paraconal interventricular branch. Св: Circumflex branch. $\left(^{*}\right)$ : Arteriovenous triangle, open at the lower end and closed at the top Source: Compiled by the authors

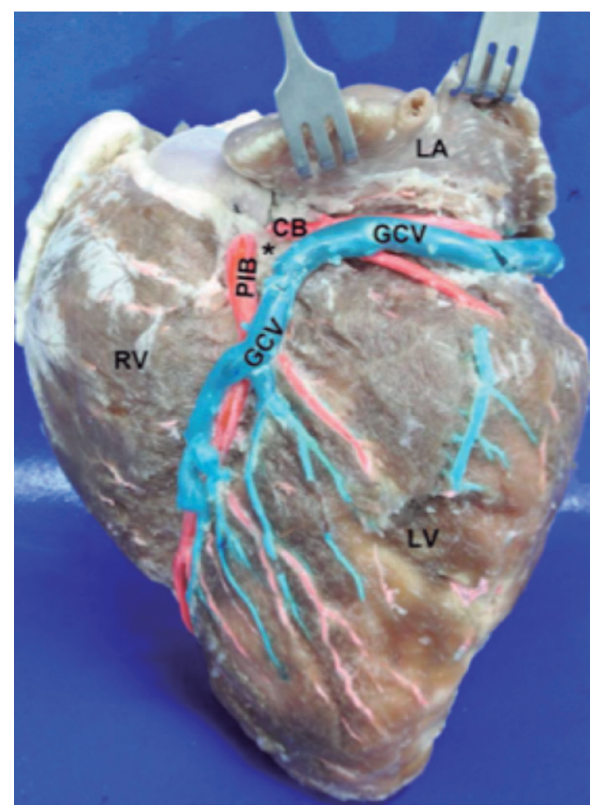

Figure 5. Left surface of the heart. LA: Left atrium. LV: Left ventricle. RV: Right ventricle. GCV: Great cardiac vein. PIB: Paraconal interventricular branch. св: Circumflex branch. $\left(^{*}\right)$ : Arteriovenous triangle, closed at the lower end and open at the top. Source: Compiled by the authors
(16.6\%), originating from the middle third of the heart in thirteen parts (21.6\%) and in eleven hearts (18.3\%) the source was found in the upper third (figure 1).

The distal caliber of the right and left marginal vein (LMV) were $2.64 \pm 0.76 \mathrm{~mm}$ and $3.81 \pm 1.07 \mathrm{~mm}$ respectively, the caliber of the azygos vein reported is $8.20 \pm 2.18 \mathrm{~mm}$.

Another observed structure was the coronary sinus (Cs), to which the proximal caliber finding a measure of $10.9 \pm 2.31 \mathrm{~mm}$, meanwhile the distal determined caliber of the same structure was 12.36 $\pm 2.33 \mathrm{~mm}$, the length is finally determined, which was $28.91 \pm 5.22 \mathrm{~mm}$ (figure 6).

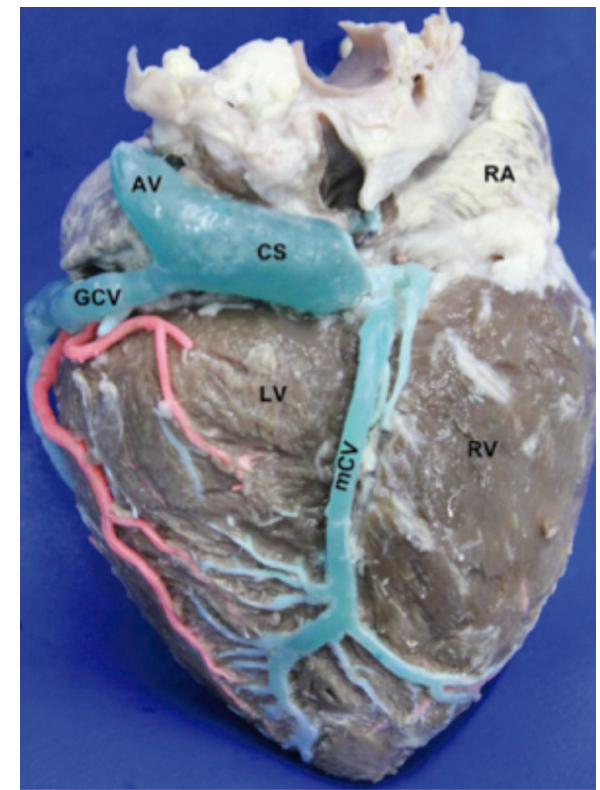

Figure 6. Right surface of the heart. RV: Right ventricle. LV: Left ventricle. RA: Right atrium. cs: Coronary sinus. MCV: Middle cardiac vein. GCV: Great cardiac vein. AV: Azygos vein

Source: Compiled by the authors

For the LMV we studied its outfall and found that in 55 of the anatomical specimens analyzed $(91.6 \%)$ this arrived to the GCV, in one heart $(1.66 \%)$ its outfall start at the cs.

Regarding the middle cardiac vein (MCV), origin and vascular anastomosis structure formed was studied. It was found that in 53 hearts (88.3\%) the origin was at the apex 13 and the lower third (11.6\%). For the second characteristic it was found that in 17 of the tested parts $(28.3 \%)$ anastomosis is 
formed with the GCV, in ten cases (16.6\%) had anastomosis with LMV in eleven hearts (18.3\%).

The shape of the cs was also determined. In 31 hearts $(51.6 \%)$ it was cylindrical, in $18(30 \%)$ the form was described as a funnel for the other anatomical parts (eleven hearts), it was unable to determine the form of this structure.

\section{Discussion}

This work allowed to describe some details of the GCV, finding that in a high proportion (70\%), this arises from the apex. Similar data have been reported in other studies [13-14], however these same contrasts are described by Pejkovic [12], who mentions that this vascular structure is also found in buffalo, goat and pig, and starts and begins in the apical groove. Likewise, the size of this structure was described, finding higher value than reported by other authors [11] $(5.36 \pm 1.04 \mathrm{~mm}$ vs. $3.73 \pm 0.79$ $\mathrm{mm})$. These results cannot be directly comparable since they are the result of studies developed with anatomical structures of animals of different ages.

The AVT was found in $96.66 \%$ of the hearts studied; this data is similar to that described in another study in which presence was reported in $97.5 \%$ of anatomical analyzed parts [11]. The configuration of this structure could not be contrasted with other studies, since no reports describing this configuration were found.

Meanwhile the study of LMV showed that this could originate from different places, such as the apex, the lower third, middle third and upper third of the heart. These data are consistent with studies in humans $[4,5,15]$ and pigs [11].

In respect to the outfall of this structure, the data are consistent with other reports [15], which also described that in over $90 \%$ of cases this leads to the GCV and a very low proportion in the beginning of the cs.

Regarding the Cs, it is evidenced that it is one of the structures more fully described, both in humans $[5,14,16,17]$ and pigs $[1,4,11]$. In humans its caliber reported at $6.12 \mathrm{~mm}$ [5], compared to the caliber this structure proximal anatomical pieces studied $10.9 \mathrm{~mm}$ for the proximal and $12.36 \mathrm{~mm}$ for distal caliber. The literature mentions that the Cs is one of the variables regarding structures' longitude and diameter [15], the shape of this structure has been studied in less detail, however, data in this study are described for cylindrical funnel shape.

\section{Conclusion}

The detailed description of the anatomical variations of pig heart opens a window that allows thinking about the compatibility of the structure with humans, alongside the development of biotechnology and immunology of transplantation.

Recognition of vascular structures in pig's hearts and its anatomic variations may contribute to the development of studies on cardiovascular surgery and diseases of great clinical importance in human.

\section{References}

[1] Crick SJ, Sheppard MN, Ho SY, Gebstein L, Anderson $\mathrm{RH}$. Anatomy of the pig heart: comparisons with normal human cardiac structure. J Anat. 1998;193(Pt 1):105-19. doi:10.1046/j.1469-7580.1998.19310105.x.

[2] Pan-Chih, Huang AH, Dorsey LM, Guyton RA. Hemodynamic significance of the coronary vein valves. Ann Thorac Surg. 1994;57(2):424-30. doi:10.1016/0003-4975(94)91009-X.

[3] Swindle MM, Bobbie DL. Comparative Anatomy of the Pig. Charles River Technical Bulletin. 1987;4(1):1-4.

[4] Sahni D, Kaur GD, Jit H, Jit I. Anatomy \& distribution of coronary arteries in pig in comparison with man. Indian J Med Res. 2008;127(6):564-70. Available from: http://www.ncbi.nlm.nih.gov/ pubmed/18765875

[5] Ortale JR, Gabriel E, Iost C, Márquez CQ. The anatomy of the coronary sinus and its tributaries. Surg Radiol Anat. 2001;23(1):15-21. Available from: http:// www.ncbi.nlm.nih.gov/pubmed/11370136

[6] Singh JP, Houser S, Heist EK, Ruskin JN. The coronary venous anatomy: a segmental approach to aid cardiac resynchronization therapy. J Am Coll Cardiol. 2005;46(1):68-74. doi:10.1016/j.jacc.2005.04.017.

[7] Gilard M, Mansourati J. Angiographic anatomy of the coronary sinus and its tributaries. Pacing and Clinical Electrophysiology. 1998;21(11):22804. Available from: http://onlinelibrary.wiley.com/ doi/10.1111/j.1540-8159.1998.tb01167.x/full

[8] Schaffler GJ, Groell R, Peichel KH, Rienmüller R. Imaging the coronary venous drainage system using electron-beam CT. Surg Radiol Anat. 2000;22(1):35- 
9. Available from: http://www.ncbi.nlm.nih.gov/ pubmed/10863745

[9] Pontone G, Andreini D, Cortinovis S, Mushtaq S, Bertella E, Annoni A, et al. Imaging of cardiac venous system in patients with dilated cardiomyopathy by 64-slice computed tomography: comparison between non-ischemic and ischemic etiology. Int J Cardiol. 2010;144(2):340-3. doi:10.1016/j.ijcard.2009.03.043.

[10] Kato T, Yasue T, Shoji Y, Shimabukuro S, Ito Y, Goto $S$, et al. Angiographic difference in coronary artery of man, doc, pig, and monkey. Acta pathol Jpn. 1987;37(3):361-73.

[11] Sousa-Rodrigues CF, Alcântara SF, Silva WNV, Alcântara SF, Olave E. Trígono arterio-venoso del corazón. Int J Morphol. 2004;22(4):291-6.

[12] Pejkovic B, Bogdanovic D. The great cardiac vein. Surg Radiol Anat. 1992;14:23-8.

[13] Loukas M, Bilinsky S, Bilinsky E, el-Sedfy A, Anderson RH. Cardiac veins: a review of the literature. Clin Anat. 2009;22(1):129-45. doi:10.1002/ca.20745.
[14] Kaczmarek M, Czerwiński F. Assessment of the course of the great cardiac vein in a selected number of human hearts. Folia Morphol (Warsz). 2007;66(3):190-193. Available from: http://www. ncbi.nlm.nih.gov/pubmed/17985317.

[15] Gómez FA, Ballesteros LE, Cortés LS. Morphologic description of great cardiac vein in pigs compared to human hearts. Rev Bras Cir Cardiovasc. 2014:63-9. doi:10.5935/1678-9741.20140101.

[16] Maros TN, Racz L, Plugor S, Maros TG. Contributions to the morphology of the human coronary sinus. Anat Anz. 1983;154(2):133-44.

[17] Van de Veire NR, Schuijf JD, De Sutter J, Devos D, Bleeker GB, de Roos A, et al. Non-invasive visualization of the cardiac venous system in coronary artery disease patients using 64-slice computed tomography. J Am Coll Cardiol. 2006;48(9):1832-8. doi:10.1016/j.jacc.2006.07.042. 